\title{
INFORME DE UN CASO: QUISTE PARASITARIO MESENTÉRICO SUMADO A INSUFICIENCIA RENAL CRÓNICA SECUNDARIO A LUPUS ERITEMATOSO SISTÉMICO EN ADOLESCENTE.
}

\author{
Tito Héctor David", Agila Edison Hernán", \\ Granja Viviana Elizabeth ${ }^{3 *}$, Paredes Andrea Elizabeth ${ }^{2}$.
}

DOI: $10.48018 /$ rmv.v32.i1.S8

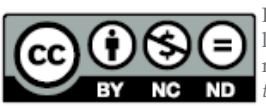

ste artículo está bajo una icencia de Creative Commons de tipo Reconocimiento - No comercial - Sin obras OPEN ACCESS derivadas 4.0 International.

1. Rio Hospital. Médico del Servicio de Emergencia. Riobamba, Ecuador.

2. Médico Consultório Privado. Quito, Ecuador

3. Médico Consultório Privado. Santo Domingo, Ecuador.

\section{ORCID ID:}

Tito Héctor David

orcid.org/0000-0001-6131-4028

Agila Edison Hernán

orcid.org/0000-0002-1301-1169

Granja Viviana Elizabeth

orcid.org/0000-0002-7573-4784

Paredes Andrea Elizabeth

orcid.org/0000-0001-7333-988X

* Corresponding author:

Granja Viviana Elizabeth

E-mail: vivi_.12@hotmail.com

Article history: Manuscript presented at the I Clinical Case Contest - Hospital Vozandes Quito February 27, 2021.

CARE 2017 Check List statement: The authors have real the CARE 2017 Check List and the manuscript was prepared and revised according to the CARE 2017 Checklist.

Conflict of interest: All authors declared that there are no conflicts of interest.

Financial disclosure: The authors have no financial relationships relevant to this article to disclose.

Forma de citar este artículo: Tito HD, Agila EH, Granja VE, Paredes AE. INFORME DE UN CASO: QUISTE PARASITARIO MESENTÉRICO SUMADO A INSUFICIENCIA RENAL CRÓNICA SECUNDARIO A LUPUS ERITEMATOSO SISTÉMICO EN ADOLESCENTE. Rev Med Vozandes. 2021; 32 (1 Suppl 1): S15-S16

\section{Resumen}

Introducción: Los quistes mesentéricos son tumoraciones abdominales de baja de incidencia. La presentación clínica depende de la localización y tamaño del quiste.

Descripción del Caso: Presentamos un caso clínico de adolescente femenina de 17 años sin antecedentes patológicos personales de importancia que acude por presentar inicialmente náuseas y vómitos incoercibles acompañados de alza térmica y dolor abdominal de 5 días de evolución, lo cual provocó deshidratación moderada consecuentemente injuria renal aguda con un aumento importante de azoados requiriendo diálisis bisemanal; El daño renal producto de dicha deshidratación llevo a una insuficiencia renal crónica agravada por el lupus eritematoso sistémico que desarrolla la paciente durante la evolución clínica de la enfermedad, presentando mialgias matutinas, pérdida de peso considerable, malestar general, fiebre sin foco y pruebas de anticuerpos antinucleares con lo que se diagnostica a la paciente de LES.

Concomitantemente la paciente presenta distención abdominal importante por lo que se realiza TAC (Tomografía) evidenciando la presencia de quiste mesentérico de gran tamaño que desplaza órganos intraabdominales, dicho quiste presenta características de equinococosis por lo que se la refiere a cirugía general. Paciente permanece a la espera de biopsia renal, para determinar la clasificación histopatológica ya que requiere diálisis trisemanal por enfermedad renal aguda grado 5, paciente no es candidata para trasplante renal por la enfermedad autoinmune de base.

Conclusión: El quiste mesentérico es una entidad de escasa frecuencia, la cirugía es el tratamiento de elección y el único método de diagnóstico definitivo para quistes mesentéricos, la paciente permanece en la espera de resolución quirúrgica 


\section{Abstract \\ Keywords: Mesenteric Cyst, Systemic Lupus Erythematosus, Echino- coccosis, Chronic Kidney \\ LEFT ACUTE APPENDICITIS; AN UNUSUAL PRESENTATION OF A VERY COMMON PATHOLOGY IN THE ECUADORIAN POPULATION. BIBLIOGRAPHIC REVIEW AND REPORT OF A CASE.}

Introduction: Mesenteric cysts are abdominal tumors with a low incidence, the clinical presentation depends on the location and size of the cyst, the recommended treatment is surgical resolution. In next pages.

Case description: We present the case of a 17-year-old female adolescent with no significant personal pathological history, who initially presented nausea and incoercible vomiting, accompanied by fever and abdominal pain of 5 days of evolution, which caused moderate dehydration and consequently acute kidney injury and later chronic kidney failure that is aggravated by systemic lupus erythematosus that the patient develops during the clinical course.

Concomitantly, the patient presents significant abdominal distention, so it is performed a CT scan (Tomography), which reveals the presence of a mesenteric cyst that displaces intra-abdominal organs, so it is made a reference to general surgery.

Patient remains awaiting renal biopsy to determine histopathological classification for underlying autoimmune disease. The patient remains awaiting surgical resolution.

Conclusion: Mesenteric cyst is a rare entity, surgery is the treatment of choice and the only definitive diagnostic method for mesenteric cysts, the patient remains awaiting surgical resolution. 